\title{
ANALISIS HUBUNGAN JANGKA PANJANG DAN JANGKA PENDEK ANTARA NPL, ROE, SIZE DAN LOTA TERHADAP CAPITAL BUFFER
}

\author{
Oleh: \\ Juni Purwati 1) \\ Dr. Sudarto, ME ${ }^{2}$ \\ Drs. Suwaryo, M.Si ${ }^{3)}$ \\ E-mail: juni.pwt03@gmail.com \\ ${ }^{2)}{ }^{3)}$ Dosen Fakultas Ekonomi dan Bisnis, Universitas Jenderal Soedirman
}

\begin{abstract}
This study aimed to analyze the effect of Non-Performing Loans, Return on Equity, bank size, and Loan to Total Assets of the capital buffer using panel data. The population in this study was State Owned Banks registered in Bank Indonesia for the period 2002 to 2014. In this study all the population used as an object of study and the type of data used in this research was quarterly data. Data were analyzed using cointegration test and Error Correction Model to demonstrate short and long term relationship. The results showed that in the short term, the Non Performing Loan and Return on Equity have a positive influence on equilibrium of capital buffers in goverment bank. Furthermore, the size of bank negatively affect the equilibrium of capital buffers in the short term. Besides the long-term relationship, the Non Performing Loan and Return on Equity also has a positive effect on the equilibrium of capital buffers in state-owned commercial banks. Meanwhile, Loan to Total Assets have a negative effect on the equilibrium of capital buffers in the long term.
\end{abstract}

Keywords : Capital Buffers, Non Performing Loan, Return on Equity, Bank Size, Loan to Total Assets, Cointegration Test, and Error Correction Model.

\section{PENDAHULUAN}

\section{Latar Belakang Masalah Penelitian}

Perbankan merupakan industri
yang kegiatannya paling banyak mendapat pengawasan dan pengaturan oleh pemerintah dibandingkan industri lainnya. Hal ini tidak lepas dari peran vital bank dalam sistem pembayaran dan penyaluran kredit kepada masyarakat. Jika sebuah bank mengalami kegagalan, dampak yang ditimbulkan akan meluas mempengaruhi nasabah dan lembagalembaga yang menyimpan dananya atau menginvestasikan modalnya di bank, dan akan menciptakan dampak lanjutan secara domestik maupun pasar internasional.

Dari informasi yang dirilis Bank Indonesia, terjadinya krisis keuangan global pada tahun 2008 ditengarai merupakan dampak dari kondisi dimana sektor perbankan di berbagai negara memiliki tingkat leverage yang tinggi, yang kemudian menggerus kualitas modal bank. Oleh karena itu, the Basel Committee of Banking Supervision $(B C B S)$ membuat serangkaian kebijakan 
yang dapat meningkatkan stabilitas sektor keuangan dan mencegah efek negatif terhadap perekonomian dari krisis yang mungkin terjadi di masa yang akan datang, yang secara substansial merevisi ketentuan tentang kewajiban modal perbankan yang sudah berjalan (yakni Basel I dan II) menjadi aturan baru yang bernama "Basel III: Global Regulatory Framework for More Resilient Banks and Banking Systems".

Perbedaan utama Basel III dengan Basel II yaitu adanya perubahan struktur permodalan, penguatan manajemen likuiditas serta adanya tambahan rasio permodalan baru berupa capital conservation buffer, counter cyclical capital buffers, dan juga leverage ratio. Sehubungan dengan adanya capital conservation buffer dan countercyclical buffer, Jokipii dan Milne (2008) mendefinisikan capital buffer sebagai jumlah modal bank yang ditahan melebihi jumlah kebutuhan yang ditentukan oleh regulasi nasional.
Dengan kata lain, capital buffer merupakan selisih lebih antara Capital Adequacy Ratio (CAR) atau rasio kecukupan modal pada masing-masing bank dengan rasio CAR minimum yang ditetapkan oleh regulasi perbankan (8\%).

Penyediaan kelebihan modal menjadi penting dikarenakan oleh disiplin pasar, intervensi pengawas (Jackson,1999 dalam Jokipii dan Milne, 2008), serta karena adanya keuntungan terhadap kesempatan pertumbuhan bank di masa yang akan datang (Jokipii dan Milne, 2008). Penyediaan capital buffer (Wong et all, 2005) juga bertujuan sebagai pelindung yang dapat menyerap berbagai risiko yang muncul jika bank mengalami kerugian (dalam Fikri, 2012), serta dapat digunakan untuk melakukan screening dan monitoring pada peminjam dengan lebih hati-hati (Agenor et all 2012 dalam $\mathrm{Vu}$ dan Turnel, 2014). Melalui Peraturan Bank Indonesia No.12/12/PBI/2013, bank di Indonesia diwajibkan membentuk

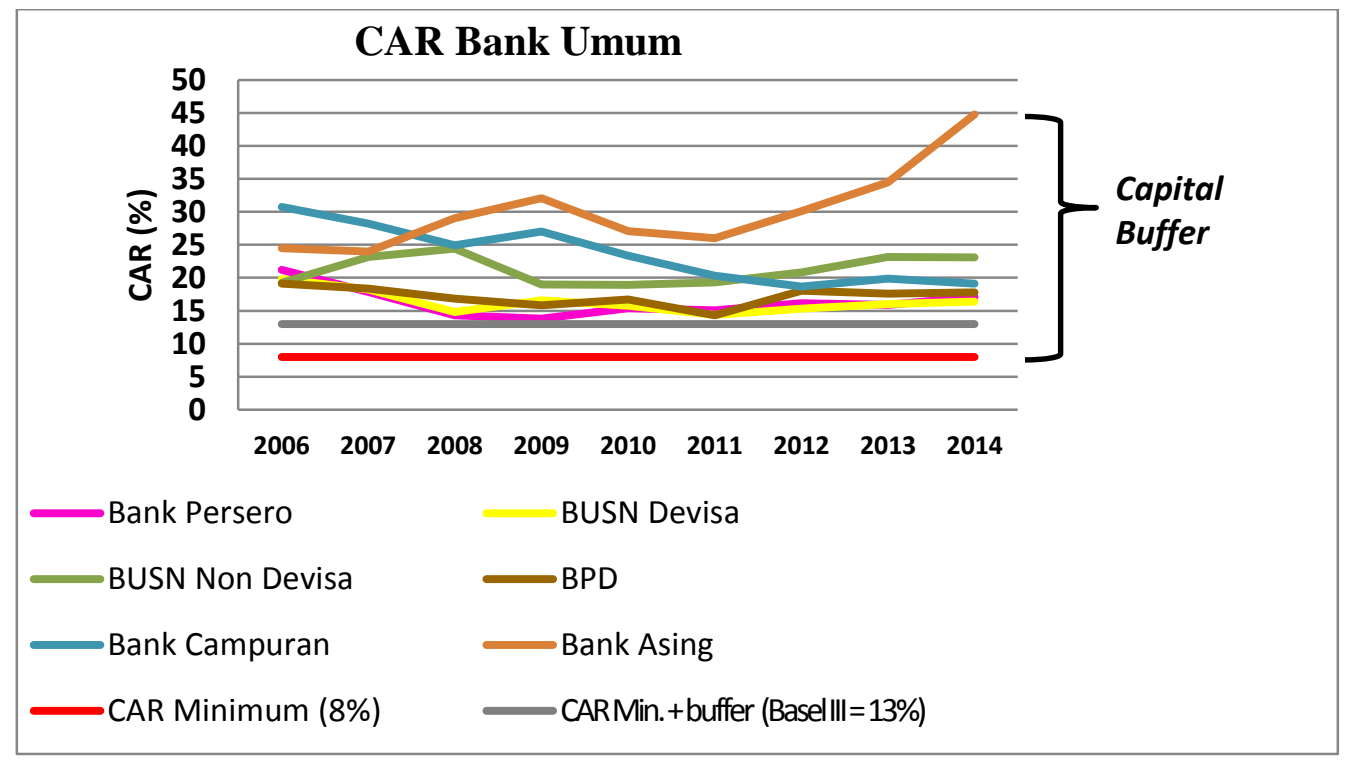

Gambar 1. Perkembangan CAR dan capital buffer Bank Umum di Indonesia. 
capital buffer yakni capital conservation buffer sebesar 2,5\% dari ATMR sedangkan countercyclical buffer berkisar $0-2,5 \%$.

Dalam konteksnya terhadap penerapan Basel III di Indonesia, tingkat rasio kecukupan modal (CAR) dan capital buffer pada bank-bank umum di Indonesia selama periode 2006 s/d 2014 cenderung tinggi dan sudah jauh di atas ketentuan yang disyaratkan Basel III, yakni CAR 8\% ditambah capital buffer yang berkisar 5\%. Dari grafik di bawah, terlihat nilai CAR dan capital buffer yang mencapai titik paling rendah di antara enam jenis bank umum di Indonesia terdapat pada bank umum persero. Oleh karena itu, penelitian ini hanya akan berfokus pada objek bank persero di Indonesia.

Memiliki capital buffer yang terlalu tinggi tidak bagus untuk industri perbankan dikarenakan modal tersebut seharusnya dapat digunakan untuk ekspansi kredit. Jika bank tidak mampu menyalurkan kredit sementara dana yang terhimpun banyak maka akan menyebabkan bank tersebut kehilangan kesempatan untuk memperoleh laba yang lebih tinggi. Meskipun sumber dana utama bagi bank dalam penyaluran kredit adalah dana pihak ketiga, namun bukan berarti ekuitas tidak dapat menjadi sumber dana yang digunakan untuk memperoleh keuntungan dengan menyalurkan kredit kepada para nasabah.

Mengikuti penelitian sebelumnya seperti Atici dan Gursoy (2013), Boucinha (2008), Tabak et all (2011), serta Jokipii dan Milne (2008), penelitian ini menggunakan rasio Non Performing Loan (NPL) sebagai proxy dari profil risiko bank.

Dari grafik tersebut diketahui bahwa nilai capital buffer (Buffer) dan

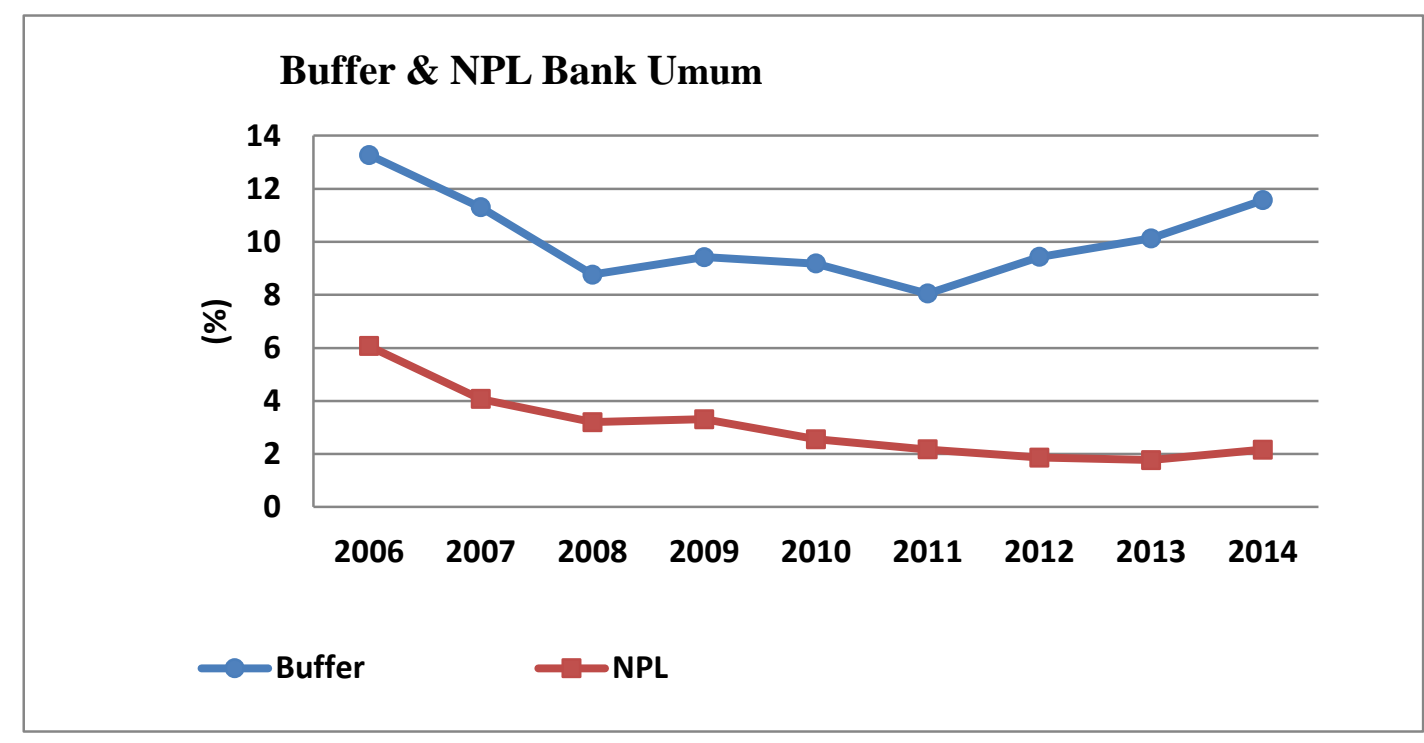

Sumber : Statistik Perbankan Indonesia (diolah)

Gambar 2. Nilai capital buffer dan NPL Bank Umum di Indonesia (\%) 
NPL bank umum di Indonesia mengalami fluktuasi yakni bergerak secara positif dari tahun 2006 sampai dengan 2011, yakni mengalami tren penurunan.. Namun kondisi ini berbeda dengan periode 2012 sampai dengan 2014 dimana fluktuasi nilai capital buffer dan Non Performing Loan bergerak secara berlawanan, yakni capital buffer mengalami peningkatan, sementara NPL mengalami penurunan. Hal ini memunculkan suatu pemikiran apakah dengan peningkatan atau penurunan kredit bermasalah akan mempengaruhi keputusan bank dalam menyediakan kelebihan modal atau tidak.

Penelitian sebelumnya, Atici dan Gursoy (2013) menggunakan Return on Equity (ROE) sebagai proxy dari capital holding cost, menyatakan bahwa informasi asimetris dapat menyebabkan peningkatan laba ditahan, yang dapat meningkatkan rasio modal. Dalam penelitian Jokipii dan Milne (2008) serta Boucinha (2008) berkaitan dengan jumlah aset yang dimiliki, bank-bank besar cenderung memiliki capital buffer yang lebih rendah dibandingkan pada bank-bank kecil karena sifat "too-big-to fail". Dalam penelitian ini Loans to Total Assets dipertimbangkan untuk menentukan apakah kondisi pertumbuhan kredit yang tinggi akan berpengaruh dalam mengurangi kapasitas bank untuk meningkatkan cadangan modal atau tidak, seperti yang dilakukan oleh Atici dan Gursoy (2013) serta Jokipii dan Milne (2008).

Analisis jangka pendek yang mengestimasi variabel-variabel penentu fluktuasi capital buffer dengan penggunaan analisis pada titik waktu yang sama terhadap capital buffer besar kemungkinan akan menghasilkan keputusan yang bias. Hal ini berkaitan dengan masalah autokorelasi dalam residual yang biasanya disebabkan oleh struktur dinamis pada variabel dependen yang tidak diikutsertakan sehingga tidak dapat menggambarkan nilai yang sebenarnya. Oleh karena itu dalam penelitian ini digunakan model analisis dinamis, karena dimungkinkan masih ada struktur yang lebih luas dalam fluktuasi capital buffer dan informasi yang lebih banyak dalam sampel yang dapat diperoleh dengan mengestimasi model sebelumnya. Namun penggunaan periode jangka pendek juga masih diperlukan untuk melihat kesesuaian dengan analisis jangka panjangnya.

Bank-bank persero di Indonesia memiliki capital buffer yang cukup tinggi di atas persyaratan modal yang telah diatur bank sentral dan juga kerangka permodalan Basel III. Namun, penelitian mengenai capital buffer di Indonesia masih belum banyak dilakukan. Di samping itu diharapkan dengan mempertimbangkan periode jangka panjang dan jangka pendek dalam penelitian ini, maka diperoleh penaksiran yang lebih baik dan keputusan yang diambil berkaitan dengan penyediaan modal bank tidak lagi menjadi bias.

\section{Tujuan Penelitian}

Sesuai dengan permasalahan penelitian yang dihadapi, maka penelitian ini bertujuan untuk :

1. Menganalisis hubungan jangka panjang antara Non Performing Loans, Return on Equity, ukuran 
perusahaan dan Loans to Total Assets terhadap capital buffer.

2. Menganalisis hubungan jangka pendek antara Non Performing Loans, Return on Equity, ukuran perusahaan dan Loans to Total Assets terhadap capital buffer.

3. Menganalisis pengaruh Non Performing Loans, Return on Equity, ukuran perusahaan, dan Loans to Total Assets terhadap capital buffer.

\section{Hipotesis}

H1 : Terdapat hubungan jangka panjang antara NPL, ROE, SIZE, dan LOTA terhadap capital buffer

H2 : Terdapat hubungan jangka pendek antara NPL, ROE, SIZE, dan LOTA terhadap capital buffer

H3.a : Non Performing Loan (NPL) berpengaruh positif terhadap capital buffer dalam jangka pendek

H3.b : Non Performing Loan (NPL) berpengaruh positif terhadap capital buffer dalam jangka panjang

H4.a : Return on Equity (ROE) berpengaruh positif terhadap capital buffer dalam jangka pendek

H4.b : Return on Equity (ROE) berpengaruh positif terhadap capital buffer dalam jangka panjang

H5.a : Ukuran Perusahaan (SIZE) berpengaruh negatif terhadap capital buffer

dalam jangka pendek

H5.b : Ukuran Perusahaan (SIZE) berpengaruh negatif terhadap capital buffer dalam jangka panjang

$\begin{aligned} \text { H6.a : } & \begin{array}{l}\text { Loan to Total Asset } \\ \text { (LOTA) berpengaruh }\end{array} \\ & \text { positif terhadap capital } \\ & \text { buffer dalam jangka } \\ \text { pendek } & \\ \text { H6.b : } & \begin{array}{l}\text { Loan to Total Asset } \\ \text { (LOTA) berpengaruh }\end{array} \\ & \text { positif terhadap capital } \\ & \text { buffer dalam jangka } \\ \text { panjang } & \end{aligned}$

\section{METODE ANALISIS}

\section{Objek Penelitian}

Objek penelitian ini adalah bank umum persero yang terdaftar di Bank Indonesia yang menerbitkan laporan keuangan kuartalan selama periode tahun 2002 s/d 2014.

\section{Populasi}

Populasi dalam penelitian ini adalah seluruh bank persero yang terdaftar di Bank Indonesia. Dalam penelitian ini, peneliti menggunakan seluruh populasi sebagai objek penelitian dengan periode pengamatan sebanyak 52 kuartal dari tahun 2002 s/d 2014.

\section{Jenis dan Sumber Data}

Jenis data yang digunakan dalam penelitian ini adalah data sekunder berupa laporan keuangan kuartalan periode tahun 2002 sampai dengan tahun 
2014 yang diperoleh melalui website masing-masing bank persero dan website OJK (www.ojk.go.id ).

\section{Definisi Konseptual dan Operasional Variabel}

a. Variabel Dependen

Variabel terikat dalam penelitian ini adalah capital buffer dari masing-masing bank persero yang terdaftar di Bank Indonesia dari tahun 2002-2014. Menurut Jokipii dan Milne (2008) mendefinisikan capital buffer secara umum sebagai jumlah modal bank yang ditahan melebihi jumlah kebutuhan yang disyaratkan oleh regulasi nasional. Dengan kata lain, capital buffer merupakan selisih lebih dari Capital Adequacy Ratio (CAR) yang dimiliki bank dengan CAR minimum yang ditetapkan Bank Indonesia selaku regulator perbankan, yakni $8 \%$.

Capital Buffer $=$ CAR perusahaan CAR minimum

b. Variabel Independen

1) Non Performing Loans (NPL)

Menurut Dendawijaya (2009), NPL merupakan rasio untuk mengukur kemampuan manajemen bank dalam mengatasi kredit bermasalah yang diberikan oleh bank. NPL diukur dari perbandingan antara kredit bermasalah terhadap total kredit, sehingga dapat dihitung dengan rumus sebagai berikut (Surat Edaran BI No.13/30/DPNP/2011) :

NPL $=\frac{\text { Kredit bermasalah }}{\text { Total kredit }} \times 100 \%$

2) Return on Equity (ROE)

ROE adalah perbandingan antara laba bersih bank dengan modal sendiri (Dendawijaya, 2005:118). ROE dapat dihitung dengan menggunakan rumus sebagai berikut (Surat Edaran BI No.13/30/DPNP/2011) :

$$
\mathrm{ROE}=\frac{\text { Laba setelah pajak }}{\text { Rata-rata ekuitas }} \times 100 \%
$$

3) Ukuran Perusahaan (SIZE)

Bank size adalah ukuran yang menentukan besar kecilnya aset yang dimiliki oleh bank (Anggitasari, 2013). Bank size diukur dengan menggunakan nilai logaritma dari total aset bank

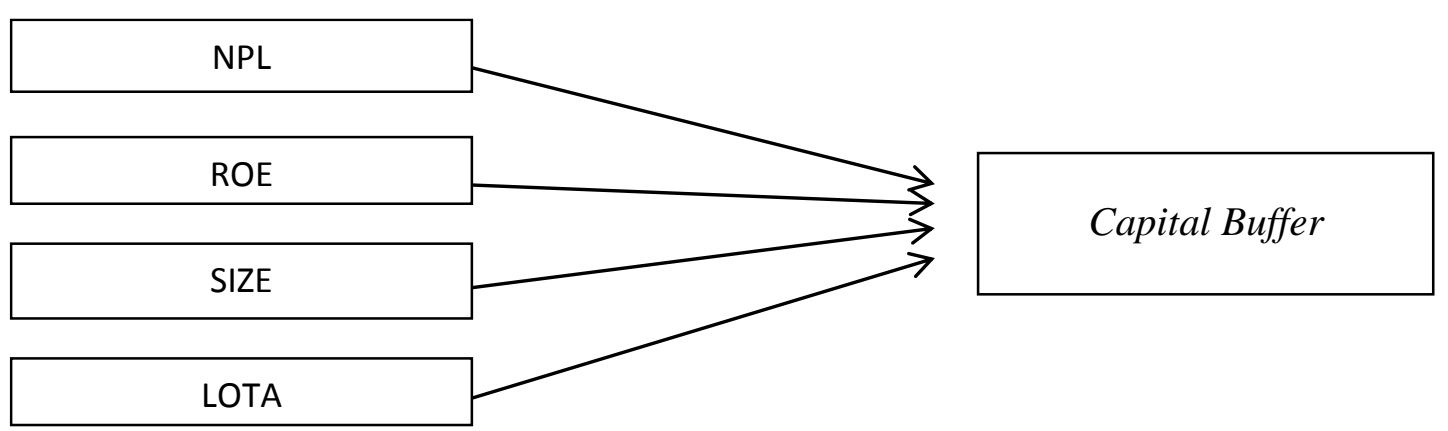

Gambar 3. Model Penelitian 
(Prasetyantoko dan Soedarmono, 2010; serta Jokipii dan Milne, 2011), sehingga dapat dirumuskan sebagai berikut:

$$
\mathrm{SIZE}=\mathrm{Ln} \text { (total aset bank) }
$$

4) Loan to Total Assets (LOTA)

Menurut Dendawijaya (2005:117) Loan to Asset Ratio adalah rasio yang digunakan untuk mengukur tingkat likuiditas bank yang menunjukkan kemampuan bank untuk memenuhi permintaan kredit dengan menggunakan total asset yang dimiliki bank. Rasio ini dapat dirumuskan sebagai berikut (Dendawijaya, 2005:117) :

$$
\text { LOTA }=\frac{\text { jumlah kredit yang diberikan }}{\text { jumlah aset }} \times 100 \%
$$

\section{TEKNIK ANALISIS DATA}

Studi ini menggunakan analisis regresi berganda dengan data panel dan menggunakan program Eviews 6 sebagai alat pengolahan data. Analisis data panel adalah gabungan dari data time series (antar waktu) dan data cross section (antar individu/ruang). Untuk data time series dalam penelitian ini, digunakan periode waktu yang panjang atau bersifat dinamis. Data dinamis ini digunakan karena nilai suatu variabel mungkin tidak hanya dipengaruhi oleh nilai variabel lain pada periode yang sama tetapi juga oleh nilai variabel pada titik waktu yang berbeda.

Data time series seringkali tidak stasioner sehingga menyebabkan regresi meragukan atau disebut regresi lancung (spurious regression). Data yang tidak stasioner seringkali menunjukkan hubungan ketidakseimbangan dalam jangka pendek, tetapi ada kecenderungan terjadinya hubungan keseimbangan dalam jangka panjang.

Sesuai dengan permasalahan tersebut maka peneliti menggunakan model analisis dinamis yakni uji kointegrasi untuk mengetahui ada tidaknya hubungan keseimbangan jangka panjang, sedangkan untuk mengetimasi hubungan jangka pendek

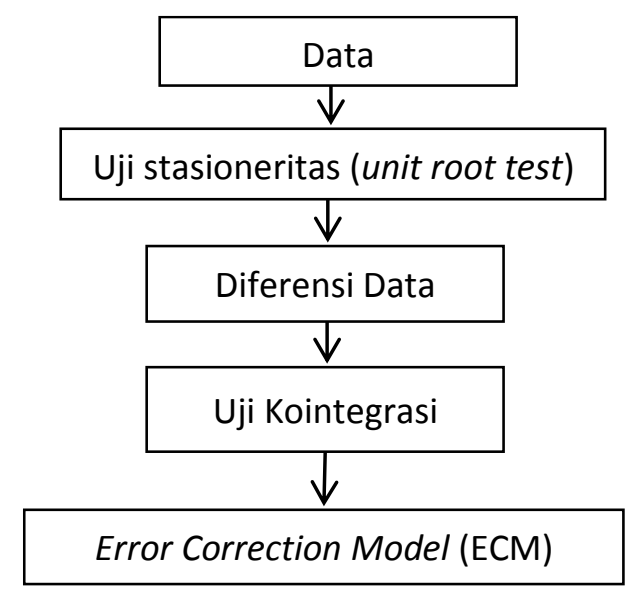

Gambar 4. Proses Penentuan Model. 
maka digunakan Error Correction Model (ECM).
2) $\mathrm{H}_{0}$ diterima jika nilai $\mathrm{t}$ statistik > nilai kritis

Tabel 1. Uji Unit Root Pada Masing-Masing Variabel

\begin{tabular}{cccccc}
\hline & & & \multicolumn{3}{c}{ Test Critical } \\
Variabel & Uji Pada & Nilai ADF Test & \multicolumn{4}{c}{} \\
\cline { 4 - 6 } & & & $\mathbf{1 \%}$ & $\mathbf{5 \%}$ & $\mathbf{1 0 \%}$ \\
\hline BUFFER & intercept & $-2,64351$ & $-3,46$ & $-2,88$ & $-2,57$ \\
NPL & intercept & $-1,20100$ & $-3,46$ & $-2,88$ & $-2,57$ \\
ROE & intercept & $-2,34983$ & $-3,46$ & $-2,88$ & $-2,57$ \\
SIZE & intercept & 4,46024 & $-3,46$ & $-2,88$ & $-2,57$ \\
LOTA & intercept & $-0,21031$ & $-3,46$ & $-2,88$ & $-2,57$ \\
\hline
\end{tabular}

Sumber : hasil output eviews 6 yang diolah

HASIL ANALISIS

\section{Penentuan Model}

a.Uji Stasioneritas Data (unit root test)

mempunyai kecenderungan mendekati nilai rata-rata dan berfluktuasi di sekitar nilai rataratanya atau memiliki ragam yang konstan. Peneliti menggunakan uji unit root (uji akar unit) untuk menentukan stasioneritas data, yakni menggunakan uji Augmented Dickey-Fuller Test (ADF Test).

Adapun hipotesis dan kriteria penerimaan hipotesis (Brooks, 2011:331) yaitu :

$$
\begin{aligned}
\mathrm{H}_{0}: & \begin{array}{l}
\text { Terdapat unit root (data } \\
\text { tidak stasioner) }
\end{array} \\
\mathrm{H}_{1}: \text { Tidak terdapat unit root } & \begin{array}{l}
\text { (data stasioner) } \\
\end{array}
\end{aligned}
$$

Kriteria :

1) $\mathrm{H}_{0}$ ditolak jika nilai t statistik < nilai kritis
Dalam penelitian ini, peneliti menggunakan taraf signifikansi 5\%. Dari hasil uji unit root tersebut, dapat dilihat bahwa nilai $t$ statistik untuk variabel BUFFER, NPL, ROE, SIZE, dan LOTA masing-masing menghasilkan angka yang lebih besar dari nilai kritis 5\%. Sehingga dapat disimpulkan bahwa semua variabel dalam penelitian ini yaitu capital buffer, Non Performing Loan, Return on Equity, ukuran perusahaan dan Loan to Total Asset tidak stasioner dalam tingkat level.

b.Uji Diferensi Data

Apabila dari hasil uji ADF diperoleh sebagian atau seluruh data tidak stasioner, maka perlu dilanjutkan pada uji derajat integrasi. Uji ini untuk mengetahui pada derajat atau order diferensi ke berapa data yang diamati akan stasioner. Uji derajat integrasi awalnya dilakukan pada tingkat 
first difference (ordo 1), dan diperoleh hasil sebagai berikut :

Seperti uji stasioneritas sebelumnya, keputusan sampai pada derajat ke berapa suatu data akan stasioner dapat dilihat dengan membandingkan antara nilai kembali dalam jangka panjang (Brooks, 2008:336).

Definisi ekuilibrium (Brooks, 2008:156) dalam konteks hubungan jangka panjang yaitu sebuah sistem dikatakan mencapai ekuilibrium (keseimbangan jangka

Tabel 2. Uji Diferensi Data Pada Tahap Pertama (First Difference) Pada MasingMasing Variabel

\begin{tabular}{clcccc}
\hline \multirow{2}{*}{ Variabel } & \multirow{2}{*}{ Uji Pada } & Nilai ADF & \multicolumn{3}{c}{ Test Critical Values* } \\
\cline { 4 - 6 } & & Test & $\mathbf{1 \%}$ & $\mathbf{5 \%}$ & $\mathbf{1 0 \%}$ \\
\hline BUFFER & intercept & $-5,69021$ & $-3,46$ & $-2,88$ & $-2,57$ \\
NPL & intercept & $-5,52372$ & $-3,46$ & $-2,88$ & $-2,57$ \\
ROE & intercept & $-4,89097$ & $-3,46$ & $-2,88$ & $-2,57$ \\
SIZE & intercept & $-11,9611$ & $-3,46$ & $-2,88$ & $-2,57$ \\
LOTA & intercept & $-7,89648$ & $-3,46$ & $-2,88$ & $-2,57$ \\
\hline
\end{tabular}

statistik ADF dengan nilai kritis distribusi statistik Dickey-Fuller. Tabel tersebut menunjukkan bahwa variabel BUFFER, NPL, ROE, SIZE, dan LOTA sudah stasioner pada diferensi pertama karena masing-masing nilai $\mathrm{t}$ statistik lebih kecil dari taraf signifikansi 5\%.

c.Uji Kointegrasi

Uji kointegrasi bertujuan untuk melihat keseimbangan jangka panjang dan memastikan adanya hubungan jangka panjang antar variabel. Menurut Engle Granger, hubungan kointegrasi dapat juga dilihat sebagai fenomena jangka panjang atau ekuilibrium, karena kemungkinan bahwa variabel yang terkointegrasi saling menyimpang dalam jangka pendek tetapi kemudian hubungan tersebut akan panjang) jika variabel mencapai pada keadaan dimana memiliki nilai yang tetap dan tidak terjadi perubahan dalam jangka panjang. Dalam penelitian ini dilakukan dengan menggunakan Uji kointegrasi Engle-Granger.

Langkah-langkah untuk uji kointegrasi dari Engle Granger yaitu :

1) Lakukan regresi persamaan Ordinary Least Square (OLS).

$$
\begin{aligned}
\text { BUFFER }= & \beta_{0}+\beta_{1} \text { NPL }+\beta_{2} \text { ROE }+ \\
& \beta_{3} \text { SIZE }+\beta_{4} \text { LOTA }+e
\end{aligned}
$$

2) Dari persamaan tersebut kemudian akan diperoleh nilai residualnya. Dari residual ini kemudian diuji unit root dengan ADF. 
3) Dari hasil estimasi nilai statistik ADF kemudian dibandingkan dengan nilai kritisnya. Jika residual tersebut stasioner, berarti regresi tersebut merupakan regresi kointegrasi (Nachrowi dan Usman, 2012:367).

Dari tabel di atas, diketahui bahwa nilai ADF tes $(-4,63518)$ lebih kecil dari nilai kritis pada taraf signifikansi $5 \%(-4,48)$ dan $10 \%(-$ 4,18 ), maka hipotesis nol yang menyatakan bahwa terdapat unit root pada residual ditolak, dan hipotesis alternatif yang menyatakan bahwa tidak terdapat unit root pada residual diterima. Oleh karena residual tersebut stasioner, maka dapat disimpulkan bahwa terdapat kointegrasi atau hubungan keseimbangan jangka panjang (long-run equilibrium) antara Non Performing Loan, Return on Equity, ukuran perusahaan, dan Loan to Total Asset terhadap capital buffer.

d. Estimasi Error Correction Model (ECM)

$\begin{array}{lr}\text { Dalam } & \text { pengujian } \\ \text { kointegrasi } & \text { sebelumnya } \\ \text { menunjukkan } & \text { bahwa } \quad \text { terdapat }\end{array}$

hubungan jangka panjang, atau keseimbangan antara variabelvariabel yang diteliti. Jelas, pada jangka pendek mungkin terjadi ketidakseimbangan

(disequilibrium) atau di antara variabel-variabel tersebut tidak mencapai keseimbangan. Menurut Sargan, Engle dan Granger, Error Correction Model adalah teknik untuk mengoreksi ketidakseimbangan jangka pendek menuju keseimbangan jangka panjang, serta dapat menjelaskan hubungan antara peubah terikat dengan peubah bebas pada waktu sekarang dan waktu lampau (Gujarati dan Porter, 2012).

Dalam penelitian ini digunakan model ECM yang dikembangkan oleh Domowitz dan El Badawi. Tahap estimasi Error Correction Model yang dikembangkan oleh Domowitz-El Badawi sebagai berikut :

1. Membentuk variabel error correction term

$$
\begin{aligned}
\mathrm{EC}_{\mathrm{t}}=\mathrm{NPL}_{\mathrm{t}-1}+\text { ROE }_{\mathrm{t}-1}+\text { SIZE }_{\mathrm{t}-1} \\
+ \text { LOTA }_{\mathrm{t}-1}-\text { BUFFER }_{\mathrm{t}-1}
\end{aligned}
$$

2. Mengestimasi persamaan ECM dengan memasukkan variabel

\begin{tabular}{|c|c|c|c|c|}
\hline \multirow[t]{2}{*}{$\begin{array}{c}\text { Nilai ADF test } \\
\text { untuk residual } \\
\text { OLS* }\end{array}$} & \multirow[t]{2}{*}{ Prob. } & \multicolumn{3}{|c|}{$\begin{array}{c}\text { Nilai Kritis Uji } \\
\text { Kointegrasi Engle } \\
\text { Granger }\end{array}$} \\
\hline & & $1 \%$ & $5 \%$ & $10 \%$ \\
\hline$-4,63518$ & 0,0000 & $-5,02$ & $-4,48$ & $-4,18$ \\
\hline
\end{tabular}

Tabel 3. Uji Kointegrasi Engle-Granger 
Error Correction (EC), sebagai berikut :

$$
\begin{aligned}
\Delta \text { BUFFER }= & \beta_{0}+\beta_{1} \Delta \text { NPL }_{i t} \\
& +\beta_{2} \Delta \text { ROE }_{i t} \\
& +\beta_{3} \Delta \text { SIZE }_{i t} \\
& +\beta_{4} \Delta \text { LOTA }_{i t} \\
& +\beta_{5} \text { NPL }_{i t-1} \\
& +\beta_{6} \text { ROE }_{i t-1} \\
& +\beta_{7} \text { SIZE }_{i t-1} \\
& +\beta_{8} \text { LOTA }_{i t-1} \\
& +\beta_{9} \text { EC }_{t}+\mathbf{e}_{\mathrm{it}}
\end{aligned}
$$

(-1), dan LOTA (-1) merupakan variabel yang menunjukkan parameter jangka panjang.

Dari tabel tersebut diperoleh koefisien variabel koreksi kesalahan (EC) bernilai positif dan secara statistik signifikan, oleh karena itu permodelan ECM yang digunakan dalam penelitian ini adalah valid. Hal ini berarti bahwa spesifikasi model yang dipakai adalah tepat dan mampu

Tabel 4. Analisis Estimasi ECM

\begin{tabular}{cccc}
\hline Variabel & Koefisien & t-statistik & Prob. \\
\hline Konstanta & $-0,692628$ & $-0,134816$ & 0,8929 \\
D( NPL) & 0,302352 & 4,173192 & 0,0000 \\
D (ROE) & 0,056166 & 2,377457 & 0,0184 \\
D (SIZE) & $-10,46167$ & $-2,851085$ & 0,0048 \\
D (LOTA) & $-0,063862$ & $-4,136891$ & 0,1007 \\
NPL (-1) & $-0,133645$ & $-1,649513$ & 0,0105 \\
ROE (-1) & $-0,192319$ & $-4,136891$ & 0,0001 \\
SIZE (-1) & $-0,135988$ & $-0,879152$ & 0,3804 \\
LOTA (-1) & $-0,212997$ & $-4,433166$ & 0,0000 \\
EC & 0,209503 & 5,021404 & 0,0000 \\
\hline R $^{2}=$ & 0,254743 & F hitung $=$ & 8,709927 \\
\hline
\end{tabular}

Sumber : hasil output eviews 6 yang diolah

Berdasarkan persamaan di atas, maka diperoleh hasil perhitungan statistik dengan bantuan software eviews sebagai berikut :

D(NPL), D(ROE), D(SIZE), dan $\mathrm{D}$ (LOTA) merupakan variabel yang menunjukkan parameter dalam jangka pendek. Sedangkan variabel NPL (-1), ROE (-1), SIZE menjelaskan variasi dinamis.

Nilai koefisien EC ini menunjukkan bahwa kecepatan penyesuaian (speed of adjustment) capital buffer untuk kembali ke kondisi ekuilibrium (keseimbangan) adalah sebesar 0,209503, yang berarti bahwa disekulibrium pada capital buffer dalam kuartal lalu akan dikoreksi pada kuartal sekarang 
Tabel 5. Nilai Koefisien Korelasi Antar Variabel Independen

\begin{tabular}{ccccc}
\hline & NPL & ROE & SIZE & LOTA \\
\hline NPL & 1,000000 & $-0,142812$ & $-0,045044$ & $-0,577187$ \\
ROE & $-0,142812$ & 1,000000 & $-0,131295$ & $-0,205966$ \\
SIZE & $-0,045044$ & $-0,131295$ & 1,000000 & 0,140136 \\
LOTA & $-0,577187$ & $-0,205966$ & 0,140136 & 1,000000 \\
\hline
\end{tabular}

Sumber : hasil ouput eviews 6 yang diolah

sebesar 20,95 persen. Dengan kata lain capital buffer tidak begitu cepat kembali ke kondisi keseimbangannya, sehingga dibutuhkan waktu sekitar 5 kuartal $(1 / 0,2095$ kuartal) untuk dapat kembali ke kondisi keseimbangan. probabilitas Jarque-Bera sebesar 0,164936 lebih besar dari nilai $\alpha$ yaitu 0,05 , sehingga dapat disimpulkan bahwa data yang digunakan berdistribusi normal.

b. Uji Multikolinieritas

Deteksi multikolinearitas

Tabel 4. Analisis Estimasi ECM

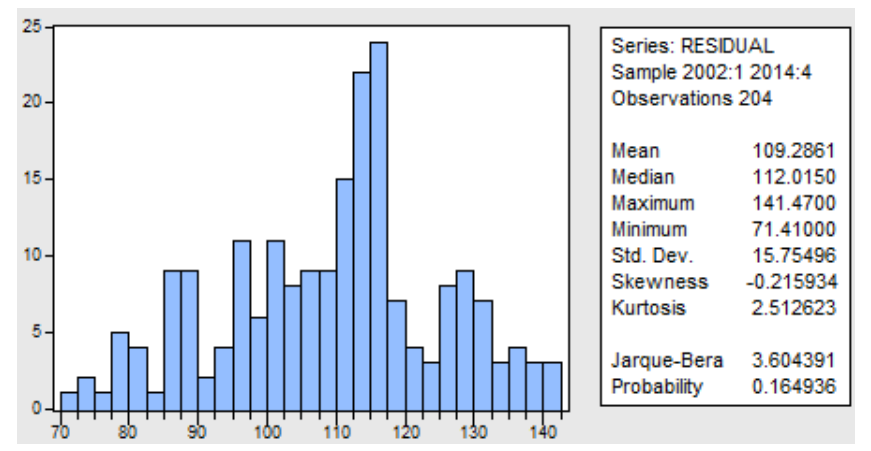

Sumber : Histogram dan Statistik untuk Residual (output eviews)

Gambar 5. Uji normalitas Jarque-Bera.

\section{Uji Asumsi Klasik}

a. Uji Normalitas

Uji normalitas yang digunakan dalam penelitian ini adalah uji Jarque-Bera. Berdasarkan hasil analisis data dengan bantuan software eviews 6 , dapat diketahui bahwa nilai dalam penelitian ini dilakukan dengan menggunakan korelasi antar variabel. Menurut Gujarati (2008) rule of thumb sebesar 0,80 , jika nilai korelasi lebih besar dari itu maka terdeteksi adanya multikolinearitas. 
Berdasarkan hasil uji di Tabel 5, diketahui nilai korelasi dari masing masing variabel $<0,80$ sehingga dapat disimpulkan bahwa tidak terdapat gejala multikolinearitas di antara variabel bebas dalam model regresi.

c. Uji Heteroskedastisitas

Untuk mengetahui gejala heteroskedastisitas dalam penelitian ini, digunakan Uji Park. Nilai statistik $t$ hitung variabel NPL, ROE, SIZE, dan LOTA lebih kecil dari nilai kritis $t$ tabel, dan juga secara statistik tidak signifikan, sehingga dapat disimpulkan bahwa hasil regresi tidak mengandung masalah heteroskedastisitas

d. Uji Autokorelasi

Uji autokorelasi bertujuan menguji apakah dalam suatu model regresi linier ada korelasi antara kesalahan pengganggu pada periode $\mathrm{t}$ dengan kesalahan pada periode sebelumnya (t-1). Untuk mengetahui ada tidaknya autokorelasi, peneliti menggunakan uji Durbin Watson (DW test).

Berdasarkan hasil estimasi ECM dengan bantuan software eviews 6 (lihat lampiran 9) yang telah dilakukan, diperoleh nilai

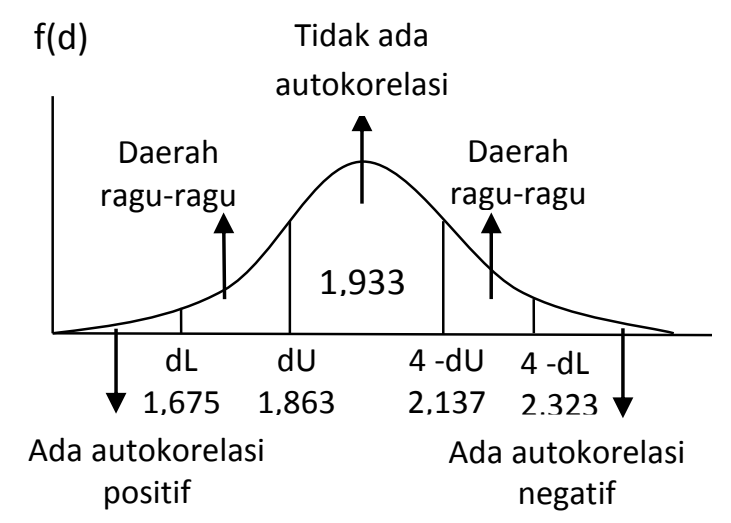

Tabel 6. Hasil Uji Park

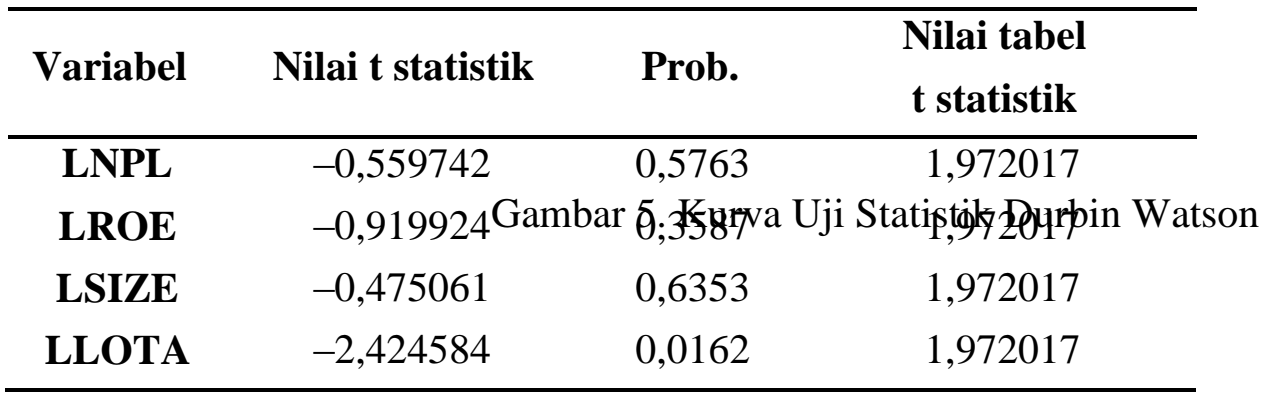

Sumber : Hasil output eviews 6 yang diolah 
Durbin-Watson sebesar 2,234001. Nilai tersebut dibandingkan dengan nilai Durbin Watson tabel ( signifikansi $5 \%$ ) dengan $\mathrm{n}=208$ dan $\mathrm{k}=9$ dan $(\alpha)=0,05$, maka dapat diketahui nilai $\mathrm{dL}=1,675$ dan $\mathrm{dU}=1,863$. Jadi nilai uji Durbin Watson berada diantara nilai 4-dU dan 4-dL, yang berarti tidak ada keputusan.

\section{Analisis Regresi Linier Berganda}

Berdasarkan hasil perhitungan statistik dengan bantuan software eviews 6 pada tabel 4 diperoleh persamaan regresi jangka pendek sebagai berikut :

$$
\begin{aligned}
& \text { BUFFER }=-0,693+0,302 \mathrm{NPL}+ \\
& 0,056 \text { ROE - 10,462 } \\
& \text { SIZE - 0,064 LOTA + }
\end{aligned}
$$

Tabel 7. Model Estimasi Jangka Panjang

\begin{tabular}{cccc}
\hline Variabel & \multicolumn{3}{c}{ Koefisien Regresi } \\
\hline Konstanta & $\beta_{0} / \beta_{9}$ & $=$ & $-3,306053$ \\
NPL & $\left(\beta_{5}+\beta_{9}\right) /$ & $=$ & \\
& $\beta_{9}$ & & 0,362086 \\
ROE & $\left(\beta_{6}+\beta_{9}\right) /$ & $=$ & \\
$\beta_{9}$ & & 0,082023 \\
SIZE & $\left(\beta_{7}+\beta_{9}\right) /$ & $=$ & \\
& $\beta_{9}$ & & 0,350902 \\
LOTA & $\left(\beta_{8}+\beta_{9}\right) /$ & $=$ & \\
$\beta_{9}$ & & $-0,016687$ \\
\hline
\end{tabular}

Sumber : perhitungan manual berdasarkan Widarjono (2009) dan Yuliadi (2009)

Oleh karena terdapat tidak ada keputusan dari uji autokorelasi ini, maka peneliti melakukan perbaikan dengan melakukan transformasi persamaan atau dikenal sebagai generalized difference equation. Dari hasil estimasi generalized difference equation diperoleh nilai DW sebesar 1,933 dimana angka tersebut terletak diantara dU dan 4dU, sehingga dapat disimpulkan bahwa model yang digunakan tidak lagi mengandung keputusan raguragu mengenai ada tidaknya autokorelasi, artinya model terbebas dari masalah autokorelasi.

$$
\mathrm{e}_{\mathrm{it}}
$$

Sedangkan besaran koefisien regresi jangka panjang model ECM harus dicari dengan menggunakan rumus sebagai berikut :

Berdasarkan hasil perhitungan statistik dengan bantuan software eviews 6 pada tabel 4 dan perhitungan sesuai rumus di atas pada tabel 7 maka diperoleh persamaan regresi jangka panjang sebagai berikut :

$$
\begin{aligned}
\text { BUFFER }= & -3,306+0,362 \mathrm{NPL}+ \\
& 0,082 \mathrm{ROE}+0,351 \mathrm{SIZE} \\
& -0,017 \text { LOTA }+\mathrm{e}_{\mathrm{it}}
\end{aligned}
$$


a. Koefisien Determinasi

Melalui perhitungan statistik diperoleh angka koefisien determinasi (adjusted $\mathrm{R}^{2}$ ) sebesar 0,254743 artinya bahwa $25,47 \%$ fluktuasi capital buffer pada bank persero dipengaruhi oleh variabel NPL, ROE, SIZE, dan LOTA. Sedangkan sisanya secara bersama-sama faktor jangka pendek dan jangka panjang Non Performing Loan, Return on Equity, ukuran perusahaan, dan Loan to Total Asset mempunyai pengaruh yang signifikan / nyata terhadap capital buffer.

Tabel 8. Rangkuman Hasil Uji t

\begin{tabular}{ccccc}
\hline Variabel & Koefisien & t hitung & $\boldsymbol{p}$-value & Pengaruh \\
\hline \multicolumn{5}{c}{ Jangka Pendek : } \\
NPL & 0,302352 & 4,173192 & 0,0000 & $(+)$ signifikan \\
ROE & 0,056166 & 2,377457 & 0,0184 & $(+)$ signifikan \\
SIZE & $-10,46167$ & $-2,851085$ & 0,0048 & $(-)$ signifikan \\
LOTA & $-0,063862$ & $-1,649513$ & 0,1007 & $(-)$ tidak signifikan \\
& & Jangka Panjang : & \\
NPL & 0,362086 & $-2,583440$ & 0,0105 & $(+)$ signifikan \\
ROE & 0,082023 & $-4,136891$ & 0,0001 & $(+)$ signifikan \\
SIZE & 0,350902 & $-0,879152$ & 0,3804 & $(+)$ tidak \\
& & & & signifikan \\
LOTA & $-0,016687$ & $-4,021404$ & 0,0000 & $(-)$ signifikan \\
EC & 0,209503 & 5,021404 & 0,0000 & signifikan \\
\hline
\end{tabular}

Sumber : hasil output eviews 6 yang diolah

sebesar $74,53 \%$ dipengaruhi oleh variabel lain yang tidak diteliti.

b. Uji F

Untuk mengetahui pengaruh NPL, ROE, SIZE, dan LOTA secara keseluruhan terhadap capital buffer maka digunakan uji F. Berdasarkan hasil analisis diketahui nilai $\mathrm{F}$ tabel pada $\operatorname{df}(\mathrm{k}-1)=8$ dan $(\mathrm{n}-\mathrm{k})=199$ sebesar 1,927, sedangkan dari hasil perhitungan diperoleh $\mathrm{F}$ hitung sebesar 8,709927.

Karena F hitung > F tabel, maka dapat disimpulkan bahwa

\section{Pengujian Hipotesis}

a. Analisis Hubungan Jangka Panjang

Dari hasil uji kointegrasi pada tabel 3 sebelumnya dimana pada persamaan OLS dengan capital buffer sebagai variabel dependen serta NPL, ROE, SIZE, dan LOTA sebagai variabel independen diperoleh bahwa residual persamaan tersebut sudah stasioner pada tingkat level, maka dapat disimpulkan bahwa terdapat kointegrasi atau hubungan 
keseimbangan jangka panjang antara variabel dalam model regresi.

b. Analisis Hubungan Jangka Pendek

Melalui analisis Error Correction Model diperoleh nilai koefisien variabel koreksi kesalahan (EC) bernilai positif dan secara statistik signifikan, oleh karena itu permodelan ECM yang digunakan dalam penelitian ini adalah valid. Hal ini berarti bahwa variabel yang digunakan dalam penelitian ini juga memiliki keseimbangan dalam jangka pendeknya.

c. Analisis pengaruh secara parsial (uji t)

Dari hasil analisis dengan menggunakan tingkat kesalahan $(\alpha)=0,05$ dan degree of freedom $(\mathrm{n}-\mathrm{k})=198$ maka diketahui nilai $\mathrm{t}$ tabel sebesar 1,972017.

\section{PEMBAHASAN}

1. H1.a = Non Performing Loan (NPL) berpengaruh positif terhadap capital buffer dalam jangka pendek

Hasil penelitian ini menunjukkan bahwa dalam jangka pendek, NPL secara signifikan mempengaruhi capital buffer secara positif. Dengan kata lain NPL mempengaruhi keseimbangan capital buffer dalam jangka pendek. Hasil penelitian ini sejalan dengan Jokipii dan Milne (2008) yang menunjukkan bahwa NPL berpengaruh positif signifikan terhadap capital buffer. Pengaruh positif dari NPL ini didukung dengan data fluktuasi nilai capital buffer dan NPL pada gambar
2 sebelumnya. Dari data yang ada pada gambar 2 sebelumnya menunjukkan bahwa NPL dan capital buffer bank umum di Indonesia pada tahun 2006 sampai 2011 bergerak secara positif, walaupun hal ini tidak terjadi lagi pada tahun 2012 sampai 2014. Hal ini berarti bank umum persero di Indonesia mengadopsi perilaku konservatif dengan tidak mau mengambil risiko.

2. H1.b = Non Performing Loan (NPL) berpengaruh positif terhadap capital buffer dalam jangka panjang

Hasil penelitian ini menunjukkan bahwa dalam jangka panjang, NPL secara signifikan mempengaruhi capital buffer secara positif. Dengan kata lain NPL mempengaruhi keseimbangan capital buffer dalam jangka panjang. Hasil penelitian ini juga sejalan dengan Tabak et all (2011) yang menunjukkan bahwa NPL berpengaruh positif signifikan terhadap capital buffer, kemudian didukung juga oleh temuan Jokipii dan Milne (2008). Sementara itu, hasil temuan ini berbeda dengan penelitian yang dilakukan oleh d'Avack dan Levasseur (2007), serta Prasetyantoko dan Soedarmono (2010), yang menunjukkan bahwa NPL mempengaruhi capital buffer dengan arah negatif, begitu juga dengan penelitian Atici dan Gursoy (2012) dengan sampel bank konvensial.

Dari pengujian kedua hipotesis mengenai variabel Non Performing Loan di atas, maka dapat disimpulkan bahwa dalam jangka pendek ketika jumlah 
kredit bermasalah naik, bank akan menambah jumlah capital buffer (modal cadangan) sebagai antisipasi kerugian bila pertumbuhan kredit perbankan berlebihan (capital conservation buffer), karena bank tidak mau mengambil risiko atas peningkatan jumlah kredit bermasalah. Kemudian kondisi ini berlangsung dalam jangka panjang karena bank akan terus menyediakan capital buffer yang lebih ketika NPL meningkat agar jumlah capital buffer tersebut mampu menutupi seluruh kredit bermasalah. Temuan ini sesuai dengan teori bahwa bank dengan risiko portofolio yang tinggi umumnya akan menahan modal yang lebih banyak.

\section{3. $\mathrm{H} 2 . \mathrm{a}=$ Return on Equity (ROE)} berpengaruh positif terhadap capital buffer dalam jangka pendek

Dalam penelitian ini ROE memiliki pengaruh positif terhadap capital buffer dalam jangka pendek. Hal ini sesuai dengan temuan Atici dan Gursoy (2012) dimana informasi asimetris dapat menyebabkan peningkatan laba ditahan, yang dapat meningkatkan rasio modal. Hal ini berarti dalam jangka pendek, ketika laba atas modal yang dimiliki meningkat, maka akan diikuti oleh peningkatan jumlah capital buffer.

\section{4. $\mathrm{H} 2 . \mathrm{b}=$ Return on Equity (ROE)} berpengaruh positif terhadap capital buffer dalam jangka panjang

Hasil penelitian ini juga menunjukkan bahwa dalam jangka panjang, ROE secara signifikan mempengaruhi keseimbangan capital buffer secara positif. Temuan ini juga sejalan dengan penelitian yang dilakukan oleh Prasetyantoko dan Soedarmono (2010) menunjukkan bahwa secara positif capital buffer dipengaruhi oleh ROE.

Dari pengujian kedua hipotesis mengenai variabel Return on Equity di atas dapat disimpulkan bahwa, dalam jangka pendek ketika jumlah laba atas modal yang ditanamkan jumlahnya naik, maka kenaikan tersebut akan dibarengi dengan penambahan jumlah capital buffer. Peningkatan jumlah capital buffer ini dimaksudkan untuk menambah antisipasi bank dalam menghadapi peningkatan jumlah kredit. Dan begitu juga dalam jangka panjang, bank akan terus meningkatkan jumlah capital buffer ketika jumlah laba atas modal yang diperoleh bank meningkat. Temuan ini sejalan dengan teori bahwa dengan adanya informasi asimetris, proporsi yang signifikan atas pergerakan laba yang diperoleh akan cenderung dijadikan sebagai laba ditahan, yang pada gilirannya akan meningkatkan rasio modal yang dimiliki.

5. H3.a = Ukuran Perusahaan (SIZE) berpengaruh negatif terhadap capital buffer dalam jangka pendek

Hasil penelitian ini mendukung teori yang ada bahwa semakin tinggi total aset yang tergambar pada rasio SIZE pada suatu bank, maka akan semakin kecil capital buffer yang disediakan oleh bank. Hal ini dikarenakan oleh kepercayaan atas ekspektasi umum "too big to fail".

6. H3.b = Ukuran Perusahaan (SIZE) berpengaruh negatif terhadap capital buffer dalam jangka panjang 
Berbeda dengan hubungan keseimbangan jangka pendek, SIZE justru tidak mempengaruhi keseimbangan capital buffer dalam jangka panjang. Hasil temuan ini berbeda dari penelitian-penelitian sebelumnya. Tidak terbuktinya pengaruh jangka panjang size terhadap capital buffer pada penelitian ini dapat disebabkan oleh perbedaan jenis dan jumlah objek penelitian dengan penelitianpenelitian sebelumnya. Sehingga dalam jangka panjang, jumlah capital buffer yang dimiliki bank tidak bergantung pada total aset yang dimiliki bank.

Dari pengujian kedua hipotesis mengenai variabel size (ukuran perusahaan) tersebut dapat disimpulkan bahwa dalam jangka panjang jumlah capital buffer tidak terpengaruh oleh besar kecilnya total aset yang dimiliki bank. Sementara itu, kondisi ini berbeda dengan keseimbangan jangka pendeknya. Total aset yang dimiliki bank akan mempengaruhi keseimbangan capital buffer dalam jangka pendek dengan arah negatif. Hal ini mengindikasikan bahwa dalam jangka pendek, ketika total aset yang dimiliki bank semakin besar, maka bank tidak akan menahan capital buffer dengan jumlah yang besar hal ini sesuai dengan teori "too big to fail", yakni bank besar akan dijamin oleh pemerintah ketika menghadapi kondisi kesulitan keuangan. Selain itu, bank besar memiliki kesempatan untuk berinvestasi dan melakukan diversifikasi yang lebih baik dari bank-bank kecil sehingga bank lebih memilih untuk ekspansi kredit daripada harus menahan modalnya untuk capital buffer.

7. H4.a = Loan to Total Asset (LOTA) berpengaruh negatif terhadap capital buffer dalam jangka pendek

Hasil penelitian ini menunjukkan bahwa dalam kondisi keseimbangan jangka pendek, variabel LOTA tidak berpengaruh terhadap capital buffer. dengan kata lain, Loan to Total Asset tidak mempengaruhi keseimbangan capital buffer dalam jangka pendek. Hal ini mengindikasikan bahwa besarnya kredit yang disalurkan atas jumlah aset yang dimiliki tidak mempengaruhi besar kecilnya jumlah capital buffer yang dimiliki bank.

8. H4.b = Loan to Total Asset (LOTA) berpengaruh negatif terhadap capital buffer dalam jangka panjang

Dalam kondisi keseimbangan jangka panjang, variabel LOTA menggambarkan kondisi yang berbeda dari keseimbangan jangka pendekya, dimana Loan to Total Asset mempengaruhi keseimbangan jangka panjang dan arahnya negatif. Hasil temuan ini sejalan dengan penelitian yang dilakukan oleh Mahakud dan Dash (2013), Prasetyantoko dan Soedarmono (2010) serta Jokipii dan Milne (2008) yang menunjukkan bahwa jumlah kredit yang disalurkan berpengaruh negatif terhadap capital buffer karena bank mengambil risiko yang lebih besar dengan menggunakan asetnya dan juga memilih untuk menahan capital buffer yang lebih rendah. 
Dari pengujian kedua hipotesis mengenai variabel Loan to Total Asset tersebut dapat disimpulkan bahwa dalam jangka pendek, jumlah kredit yang disalurkan yang dijamin dari total asetnya, tidak akan mempengaruhi jumlah besar kecilnya capital buffer yang dimiliki bank. Namun, hal ini tidak berlangsung lama, karena LOTA mempengaruhi keseimbangan capital buffer dalam jangka panjang. Oleh karena itu, ketika jumlah kredit yang disalurkan tinggi, maka akan memperkecil kapasitas bank menaikkan cadangan modal (capital buffer). Bank lebih memilih untuk mengambil risiko atas kredit yang disalurkan dengan aset yang dimiliki daripada dengan menambah jumlah modal untuk dicadangkan sebagai antisipasi atas risiko tersebut, dalam hal ini adalah capital countercyclical buffer.

\section{KESIMPULAN DAN IMPLIKASI}

\section{Kesimpulan}

1. Terdapat hubungan jangka panjang antara NPL, ROE, SIZE dan LOTA terhadap capital buffer.

2. Terdapat hubungan jangka pendek antara NPL, ROE, SIZE dan LOTA terhadap capital buffer.

3. Non Performing Loan (NPL) berpengaruh positif terhadap capital buffer dalam jangka pendek.

4. Non Performing Loan (NPL) berpengaruh positif terhadap capital buffer dalam jangka panjang.
5. Return on Equity (ROE) berpengaruh positif terhadap capital buffer dalam jangka pendek.

6. Return on Equity (ROE) berpengaruh positif terhadap capital buffer dalam jangka panjang.

7. Ukuran perusahaan (SIZE) berpengaruh negatif terhadap capital buffer dalam jangka pendek.

8. Ukuran perusahaan (SIZE) tidak berpengaruh terhadap capital buffer dalam jangka panjang.

9. Loan to Total Asset (LOTA) tidak berpengaruh terhadap capital buffer dalam jangka pendek.

10. Loan to Total Asset (LOTA) berpengaruh negatif terhadap capital buffer dalam jangka panjang.

\section{Implikasi}

Berdasarkan pengaruh Non Performing Loan, Return on Equity, Size, dan Loan to Total Asset terhadap capital buffer, maka dapat diberikan implikasi terhadap manajemen bank umum persero sebagai berikut :

1. Manajemen bank persero sudah sangat baik dalam menyediakan jumlah capital buffer. Namun, manajemen bank perlu merumuskan kembali kebijakan mengenai standar capital buffer yang berlaku agar modal yang dimiliki dapat digunakan secara efektif demi keuntungan para pemegang saham, karena capital buffer yang dimiliki bank sudah jauh melebihi ketentuan kerangka permodalan Basel III. Bank dapat menambah capital buffer dengan tidak terlalu banyak dalam 
membagikan dividen kepada para pemegang saham, sehingga menambah laba ditahan yang kemudian dijadikan sebagai capital buffer.

2. Langkah yang dilakukan manajemen dalam menghadapi peningkatan jumlah kredit sudah baik, yakni dengan menggunakan aset yang dimiliki untuk mengcovernya dan ketika jumlah kredit tersebut menjadi kredit bermasalah, manajemen kemudian memutuskan untuk menambah jumlah capital buffer untuk mengantisipasi kredit macet tersebut. Cara yang dapat dilakukan manajemen bank untuk meningkatkan capital buffer dalam hal ini yakni dengan mengurangi penyaluran kredit kepada sektor-sektor yang memiliki risiko kredit macet yang tinggi dan kemudian memperbanyak penyaluran kredit pada sektor-sektor yang mempunyai risiko kecil seperti investasi pada Sertifikat Bank Indonesia, Surat Utang Negara, ataupun penempatan di Bank Indonesia. Namun, hal ini akan berdampak pada berkurangnya laba perusahaan karena hilangnya kesempatan bank untuk ekspansi kredit dengan modal yang dimiliki, oleh karena itu manajemen perlu mengawasi jumlah kredit yang disalurkan agar tidak menjadi kredit macet. Penyaluran kredit kepada sektor yang menghasilkan return tinggi dapat dilakukan jika capital buffer sudah berada pada posisi aman.

3. Manajemen bank harus cerdas dalam menentukan proporsi alokasi laba yang diperoleh untuk ekspansi kredit dan cadangan modal (capital buffer).
4. Walaupun ketika total aset yang dimiliki bank naik, namun bukan berarti bank harus selalu menurunkan capital buffer yang dimilikinya. Hal ini dilakukan jika jumlah capital buffer yang dimiliki sudah berada di atas ketentuan yang sudah ditentukan Bank Indonesia yang mengikuti himbauan Basel III, yakni capital conservation buffer sebesar 2,5\% dan capital countercyclical buffer 0-2,5\%, sehingga total capital buffer yang harus dimiliki bank adalah minimum sebesar $5 \%$.

\section{DAFTAR PUSTAKA}

Anggitasari, A. A. 2013. Hubungan Simultan Antara Capital Buffer dan Risiko. Skripsi. Fakultas Ekonomika dan Bisnis Universitas Diponegoro. Semarang (Tidak dipublikasikan).

Atici, G. dan Guner, G. 2012. The Determinants of Capital Buffer in the Turkish Banking System. International Business Research Vol.6, No 1; December 2013.

Boucinha, Miguel. 2008. The Determinants of Portuguese Bank's Capital Buffers. Banco De Portugal Economics and Research Department. Legal Deposit no.3664/83 ISSN 0870-0117; ISBN 978-989-8061-23-2.

Brooks, Chris. 2008. Introductory Economics for Finance. Cambridge University Press. United States of America, New York. 
Dendawijaya, Lukman. 2005. Manajemen Perbankan Edisi Kedua. Ghalia Indonesia. Bogor.

Departemen Penelitian dan Pengaturan Perbankan. 2012. Consultative Paper Basel III: Global Regulatory Framework for More Resilient Banks and Banking System. Bank Indonesia. Jakarta.

Direktorat Penelitian dan Pengaturan Perbankan. 2006. Implementasi Basel II di Indonesia. Bank Indonesia. Jakarta.

Direktorat Perizinan dan Informasi Perbankan. 2006. Statistik Perbankan Indonesia. Bank Indonesia. Jakarta.

.2014. Statistik Perbankan

Indonesia. Bank Indonesia. Jakarta.

Gujarati, Damodar N., dan Porter, Dawn C. 2012. Dasar-dasar Ekonometrika Buku 2 Edisi 5 Basic Econometrics 5th edition. Salemba Empat. Jakarta. .2012 Dasar-dasar Ekonometrika Buku 1 Edisi 5 Basic Econometrics 5th edition. Salemba Empat. Jakarta.

Jokipii, T. dan Milne, A. 2008. The Cyclical Behaviour of European Bank Capital Buffers. Journal of Banking \& Finance 32 (2008) 1440-1451. ELSEVIER.

Kasmir. 2012. Manajemen Perbankan Edisi Revisi. RajaGrafindo Persada. Jakarta.
Mahakud, Jitendra dan Dash, S.R. 2013. Impact of business cycle on bank capital buffers: Evidence from india. Economics, Management, and Financial Markets Volume 8(2), 2013, pp. 110-127, ISSN 1842-3191.

Nachrowi, N.D. dan Usman H. 2006. Ekonometrika Untuk Analisis Ekonomi dan Keuangan. Lembaga Penerbit FE UI. Jakarta.

Prasetyantoko, A. dan Wahyoe, S. 2010. Faktor-Faktor Penentu Cadangan Modal di Perbankan Indonesia. Kajian Stabilitas Keuangan No.15 September 2010. Biro Stabilitas Sistem Keuangan Bank Indonesia. Jakarta.

Tabak, B.M.,Noronha, A.c., dan Cajueiro, D. 2011. Bank capital buffers, lending growth and economic cycle: empirical evidence for Brazil. Paper for the 2nd BIS CCA Conference on "Monetary policy, financial stability and the business cycle". May 2011.

Yuliadi, Imamudin. 2009. Ekonometrika Terapan. Unit Penerbit Fakultas Ekonomi (UPFE-UMY). Yogyakarta.

Widarjono, $\quad$ Agus. 2009. EKONOMETRIKA Pengantar dan Aplikasinya. EKONISIA. Yogyakarta.

www.bi.go.id diakses pada 2014 www.bni.co.id diakses pada 2015 
www.btn.co.id diakses pada 2015

www.mandiri.co.id diakses pada 2015

www.ojk.go.id diakses pada 2015 